\title{
A PERDA DA MULTIPROPRIEDADE IMOBILIÁRIA POR USUCAPIÃO
}

\author{
Marcelo Sampaio Siqueira \\ Doutor em Direito Constitucional pela Universidade de \\ Fortaleza (UNIFOR). Mestre e graduado em Direito pela \\ Faculdade de Direito da Universidade Federal do Ceará \\ (UFC). Bacharel em Ciências Econômicas pela \\ Universidade de Fortaleza (UNIFOR). Professor Titular V \\ de Direito Civil do Centro Universitário 7 de Setembro \\ (UNI7). Procurador-Chefe da Procuradoria de \\ Desenvolvimento e Pesquisa da Procuradoria-Geral do \\ Município de Fortaleza (Prodesp/PGM). \\ E-mail: msiqueira@siqueiraibiapina.com.br

\section{Natércia Sampaio Siqueira} \\ Doutora em Direito Constitucional pela Universidade de \\ Fortaleza (UNIFOR). Mestre em Direito Tributário pela \\ Universidade Federal de Minas Gerais (UFMG). Professora \\ do Programa de Pós-Graduação em Direito Constitucional \\ da Universidade de Fortaleza (UNIFOR). Procuradora do \\ Município de Fortaleza. \\ E-mail: naterciasiqueira@yahoo.com.br
}

RESUMO: Este artigo aborda assunto referente ao Direito Civil, especificamente a questão da aquisição por usucapião de bem imóvel originário de multipropriedade e suas consequências legais, sob a ótica do Direito Real. Nessa perspectiva, também analisa a natureza jurídica da multipropriedade e se a mesma pode ser perdida por usucapião. No tocante a metodologia, afirma-se que a pesquisa possui natureza bibliográfica, cujo foco foi a busca da análise do instituto da multipropriedade no Direito comparado e qual o tratamento legal da matéria no Direito pátrio. Em arremate, avaliou-se e concluiu-se que a não utilização da posse no espaço de tempo destinado à sua fruição poderá levar o multiproprietário à perda de seu Direito Real em benefício de outrem, que passa a adquiri-la, se o substituir na posse durante o prazo assinalado no Código Civil.

PALAVRAS-CHAVE: Propriedade; Multipropriedade; Aquisição; Processo; Usucapião.

\section{The loss of real estate property by adverse possession}

ABSTRACT: This article approaches subject related to Civil Law, specifically the question of the acquisition by adverse possession of immovable property from timeshares and its legal consequences, from the Real Right view. In this perspective, also examines the legal nature of the timeshares and if the same can be lost by adverse possession. The research, a bibliographical one in nature, still tried to get the theme on timeshares in Comparative Law and which treatment the absence of legal treatment of matter in Brazilian Law. In finish, evaluates and concluded that the non-use of the possession in the space of time possibility to acquire part of the timeshares by adverse possession, observed the period indicated in the Civil Code.

KEYWORDS: Property; Time Sharing; Acquisition; Due process; Adverse possession. 


\section{INTRODUÇÃO}

O presente artigo investiga essencialmente o uso da propriedade imobiliária urbana organizada sob o sistema de multipropriedade, denominado no Direito estrangeiro de time sharing, e a aplicação da usucapião a esse instituto, o que poderia implicar na perda do direito ao bem por um dos multiproprietários, analisando simultaneamente as restrições de ordem constitucional e legal oriundas tanto da imperativa função social da propriedade como da posse.

Justifica-se sua produção pela recente funcionalização da propriedade e o aparecimento de figuras híbridas de exercício de suas faculdades, que passa a não ser exclusiva. Não é objeto do estudo a descrição das faculdades da propriedade imobiliária, mas a análise do recente instituto da multipropriedade, originário do Direito europeu, sua natureza jurídica (Direito Real ou Pessoal), a falta de regulamentação específica no direito pátrio, e as suas características.

O problema específico a ser respondido neste artigo é se o instituto da usucapião pode ser aplicado a multipropriedade, o que geraria por consequência a perda de direito dominial pela prescrição aquisitiva. Ressalta-se que este tópico não se encontra tipificado no texto do projeto de lei 7.553/2017, aprovado em outubro de 2017 na comissão de Constituição e Justiça e de cidadania da Câmara dos Deputados.

Em suma, delimitando a problemática, não se analisa a perda do direito de todos os multiproprietários ao bem imóvel, mas a possibilidade de um deles ter seu direito extinto por usucapião de terceiro, que passa a usufruir da propriedade temporária no período destinado ao que sofreu a denominada prescrição aquisitiva.

O trabalho foi desenvolvido com esteio em pesquisa bibliográfica nacional e estrangeira, fazendo uma pesquisa acerca da natureza jurídica da multipropriedade imobiliária e do instituto da usucapião, com a construção de quadro comparativo do direito anterior com o vigente e menção a aspectos pontuais das recentes inovações legislativas trazidas no contexto procedimental para o reconhecimento deste tipo de prescrição aquisitiva.

$\mathrm{Na}$ contextualização do problema lançado segue-se o seguinte roteiro: por primeiro aborda-se a multipropriedade imobiliária, após expõe-se a evolução e requisitos do instituto da aquisição da propriedade imobiliária por usucapião e, por fim, estuda-se a possibilidade ou não da aquisição da multipropriedade por essa via, com base no princípio da função social da posse.

\section{A Multipropriedade no Direito Brasileiro}

Não se estabelece como ambição deste artigo trabalhar de forma sistemática o conceito de propriedade imobiliária urbana, tampouco esgotar a análise do assunto multipropriedade no Brasil, cuja natureza jurídica encontra-se no centro do problema, isto é, esse instituto constitui uma espécie de Direito real ligado a propriedade imobiliária? ${ }^{1}$

A multipropriedade é um engenho pensado e criado primordialmente por incorporadores imobiliários desejosos de edificar empreendimentos em locais turísticos, consistente na organização de grandes grupos para financiar a construção de edifícios com várias unidades autônomas, mas em número inferior ao dos membros do grupo adquirente. A engenhosidade da ideia não é

\footnotetext{
1 Siqueira (2012, p. 25-26) ao tratar da propriedade anotou: "Tradicionalmente, a propriedade tem como origem uma convenção humana e pode ser definida como o poder que o indivíduo ostenta sobre uma coisa, estando nela presentes as faculdades de usar, gozar, dispor e reivindicar, não sendo essas exaustivas ou absolutas, podendo inclusive alguns dos poderes estar momentaneamente dissociados ou compartilhados.”.
} 
baratear o preço da unidade, mas facilitar a viabilização do empreendimento ao promover a aquisição de uma mesma unidade por pessoas, muitas vezes desconhecidas entre si, reunidas em grupos, que compartilhariam as faculdades da unidade autônoma, cada qual em determinado espaço de tempo. O objetivo desta organização é que o compartilhamento das unidades construídas reduziria sensivelmente os valores efetivamente desembolsados por cada adquirente, desejoso, por exemplo, de possuir uma casa de veraneio, em comparação aos praticados se a unidade tivesse um único comprador.

Doutrinadores como Tepedino (1993) escrevem que essa ideia provavelmente teve origem na França na década de 1960 do século passado, propagando-se rapidamente a outros países europeus, com destaque para a Itália, onde recebeu a denominação de multiproprietà, e Portugal, no qual se apresenta como direito real de habitação.

No Brasil não há qualquer legislação específica sobre o caso ${ }^{2}$, embora civilistas como Caio Mário da Silva Pereira (2014) já discutam o assunto desde a década de 1980 do século passado, existindo uma tendência desde então de considerá-lo uma espécie de condomínio edilício, tendo como fundamento a Lei no 4.561/64 e, atualmente, o Código Civil de 2002.

Tepedino (1993, p. 1) leciona que “[...] com o termo multipropriedade designa-se, genericamente, a relação jurídica de aproveitamento econômico de uma coisa móvel ou imóvel, repartida em unidades fixas de tempo, de modo que diversos titulares possam, cada qual a seu turno, utilizar-se da coisa com exclusividade e de maneira perpétua”.

Do conceito apresentado destacam-se os seguintes elementos: a) bem móvel ou imóvel; b) pluralidade de detentores de direito sobre a coisa; c) repartição do aproveitamento econômico (fragmentação de uso e gozo); c) turnos intercorrentes de aproveitamento definidos com exclusividade; d) utilização exclusiva, sem o concurso dos demais nos períodos previamente definidos.

Observando-se decisões judiciais e a doutrina que trata do tema, citada nas referências, costuma-se, considerando a natureza jurídica do instituto, classificá-lo em três diferentes espécies: a) multipropriedade acionária; b) multipropriedade real; e c) multipropriedade obrigacional. A primeira ganha essa terminologia pelo fato de o equipamento vir a ser edificado por uma sociedade anônima constituída para esse fim, cujos acionistas seriam os detentores dos direitos de posse temporária das unidades que compõem o edifício. A segunda não se caracteriza por contrato social ou estatuto, mas pela propriedade em comum do edifício, sobre a qual os particulares gozariam de direito real, haja vista tratar-se de espécie de propriedade em condomínio. A terceira espécie de multipropriedade é considerada por aqueles que defendem a natureza de Direito Pessoal para o instituto em análise. Nesta última, a posse compartilhada em turnos intercorrentes das unidades autônomas da edificação seria viabilizada por uma espécie de contrato entre os interessados, sendo, portanto, o proprietário pessoa estranha aos detentores do direito de posse.

\footnotetext{
2 Recentemente encontra-se em tramitação no Senado Federal o Projeto de Lei n 54/2017 de autoria do Senador Wilder Morais, cuja explicação da ementa é: Disciplina a multipropriedade (ou propriedade fracionada), como aproveitamento econômico de coisa móvel ou imóvel, em frações de tempo fixas e reiteradas, visando à utilização exclusiva dos titulares, cada qual a seu turno. Estabelece que o direito real de multipropriedade é perpétuo e que o condomínio edilício pode ser instituído em regime de multipropriedade em relação às unidades autônomas. Ver: https://www25.senado.leg.br/web/atividade/materias/-/materia/128330. Cita-se também, contendo o mesmo objeto, o Projeto de Lei 469/2016 de autoria do Senador Deca. Ver: http://www25.senado.leg.br/web/atividade/materias/-/materia/127826.
} 
No Brasil, essa questão ganha relevância em face da falta de legislação regulatória da multipropriedade e da existência de julgados ${ }^{3}$, principalmente no início dos anos 2000, atestando o caráter obrigacional do instituto ${ }^{4}$.

A multipropriedade acionária não deixa de apresentar semelhança com a obrigacional, pois os direitos de utilização serão regulados por um negócio jurídico, não sendo os denominados detentores de uso proprietários do edifício. Talvez a espécie mais aceita, em face das características apontadas neste tópico e nas legislações estrangeiras (LEGGE 11 dicembre 2012, n. 220, que alterou o artigo 1117 do Código civil italiano ${ }^{5}$ e Dec.lei 22/2002, de 31 de janeiro, que alterou o Dec.lei 275/93, de 5 agosto, que trata do regime jurídico da habitação periódica da República Portuguesa), fosse a multipropriedade real, na qual o domínio da coisa pertenceria a multiproprietários, com direitos regulados por um regimento, que não deixa de ter natureza negocial, mas o bem seria dos próprios detentores da posse.

Aparentemente, no Brasil, a espécie multipropriedade imobiliária teria viabilidade contestada, haja vista a inexistência de qualquer norma que a classifique como Direito Real. Logo, em face do entendimento de que Direitos Reais seriam aqueles citados expressamente no ordenamento jurídico (numerus clausus), afastar-se-ia a referida classificação.

O fato de não existir uma legislação específica para regular a matéria não impede os estudiosos do Direito de apresentarem suas conclusões, cujo ponto nodal está na forma de constituição do empreendimento organizado pelo empreendedor. Nesse diapasão a Multipropriedade poderia ser classificada como típica e atípica.

Na multipropriedade típica o empreendimento pertenceria a todos os multiproprietários, a quem caberia uma fração ideal, constituindo uma espécie de condomínio edilício, regulado pelo Código Civil de 2002 e as regras ainda vigentes da Lei ${ }^{\circ} 4.591 / 64^{6}$, sendo, portanto, Direito Real. Já na atípica a propriedade seria de uma única pessoa jurídica e existiria contrato regulando a posse/uso temporária dos chamados multiproprietários, terceiros estranhos aos condôminos.

3 TJRJ, Recurso n ${ }^{\circ}$ 2002.700.023695-8, 11.03.2003 e 2. ${ }^{\circ}$ TACivSP, Ap s/ Rev n ${ }^{\circ}$ 513.448-00/7, $5^{\text {a }}$ Câmara, j. $12 / 5 / 1998$.

4 Sobre a questão vide Melo (2011, p. 25): "Embora a doutrina acabe por não enunciar essa espécie de multipropriedade, parte da jurisprudência nacional mais conservadora classifica os contratos de aproveitamento por tempo como mero direito obrigacional, alguns definindo o instituto como arrendamento.".

5 L'articolo 1117 del codice civile e' sostituito dal seguente: "Art. 1117. - (Parti comuni dell'edificio). - Sono oggetto di proprieta' comune dei proprietari delle singole unita' immobiliari dell'edificio, anche se aventi diritto a godimento periodico e se non risulta il contrario dal titolo: 1) tutte le parti dell'edificio necessarie ll'uso comune, come il suolo su cui sorge l'edificio, le fondazioni, i muri maestri, i pilastri e le travi portanti, i tetti e i lastrici solari, le scale, i portoni di ingresso, i vestiboli, gli anditi, i portici, i cortili e le facciate; 2) le aree destinate a parcheggio nonche' i locali per i servizi in comune, come la portineria, incluso l'alloggio del portiere, la lavanderia, gli stenditoi e i sottotetti destinati, per le caratteristiche strutturali e funzionali, all'uso comune; 3) le opere, le installazioni, i manufatti di qualunque genere destinati all'uso comune, come gli ascensori, i pozzi, le cisterne, gli impianti idrici e fognari, i sistemi centralizzati di distribuzione e di trasmissione per il gas, per l'energia elettrica, per il riscaldamento ed il condizionamento dell'aria, per la ricezione radiotelevisiva e per l'accesso a qualunque altro genere di flusso informativo, anche da satellite o via cavo, e i relativi collegamenti fino al punto di diramazione ai locali di proprieta' individuale dei singoli condomini, ovvero, in caso di impianti unitari, fino al punto di utenza, salvo quanto disposto dalle normative di settore in materia di reti pubbliche".

6 O Código Civil de 2002 não revogou expressamente a parte que tratava do condomínio na Lei nº 4.591/64, permitindo que se conclua que se encontra vigente naquilo que não contradizer a lei nova. Pode-se justificar este posicionamento já que a nova lei (Código Civil) não é inteiramente contrária ao próprio espírito da antiga. Exemplo disso é a aplicação do artigo 12 da Lei no 4.591/64 com o artigo 1.366 do Código Civil para tratar da validade da estipulação, em convenção de condomínio, do pagamento das despesas condominiais de forma proporcional à fração ideal (MINAS GERAIS. Tribunal de Justiça. AC n ${ }^{\circ}$ 10024112117346001/MG. Relator(a): Arnaldo Maciel. Órgão Julgador: $18^{\text {a }}$ Câmara Cível. Publicação: 07/02/2014. Julgamento: 4 de fevereiro de 2014). Pereira (2014, p. 50) atesta que a parte que trata do condomínio na Lei $4591 / 64$ foi derrogada por força do artigo $2^{\circ}, \S 1^{\circ}$. da Lei de Introdução às normas do Direito Brasileiro. 
Seria espécie de Direito Pessoal: multipropriedade obrigacional ou acionária, a depender da constituição.

Não resta dúvida que a edificação, objeto de um empreendimento organizado no formato time sharing, possuirá áreas comuns e unidades autônomas, incidindo a chamada multipropriedade nas últimas, dado o caráter de exclusividade em seu uso e gozo, mesmo limitado pelo tempo, assemelhando-se a uma espécie de condomínio edilício propriamente dito, mas possuidor de relações jurídicas complexas, em face da pluralidade de detentores de fração ideal e de direitos existentes sobre uma mesma unidade.

O ponto diferenciador, considerando a propriedade imobiliária tradicional, trazido pela multipropriedade imobiliária é que apenas no lapso temporal destinado a cada multiproprietário caber-lhes-iam as faculdades da propriedade de forma plena, com as devidas limitações de ordem constitucional (exemplo: função social da propriedade), legal (exemplo: direito de vizinhança) e regimental (exemplo: convenção e regimento do condomínio).

Para melhor esclarecimento da situação, observa-se, citando Tepedino (1993, p. 107), que há duas relações a serem consideradas - a existência de um grupo com direito a unidades por uma certa fração de tempo e as relações derivadas da convivência do grupo, tendo por base as áreas comuns. Mais adiante, na mesma página, o autor expõe:

\begin{abstract}
Tal circunstância demonstra o regime bifronte da relação jurídica em tela: a multipropriedade requer uma disciplina que compatibilize a utilização por turno das unidades exclusivas (propriedades individuais) com as áreas comuns, necessariamente integradas em um complexo imobiliário, compostas não somente pelo solo e demais espaços de propriedade coletiva, mas também pelas frações de tempo interpostas entre turnos dos diversos multiproprietários, que viabilizaram a alternância do aproveitamento dos apartamentos (propriedade comum).

A duplicidade de regimes jurídicos normalmente passa despercebida nas monografias estrangeiras sobre o tema. Entretanto, apresenta-se essencial para a correta compreensão do fenômeno verificar que o exercício do direito (de aproveitamento exclusivo) do multiproprietário não pode ser concebido fora da perspectiva de sua inserção em solo comum, no regime de compropriedade, dividido em frações abstratas entre os titulares.
\end{abstract}

A complexidade de relações envolvendo os multiproprietários e a existência de áreas comuns e áreas autônomas aproxima, no entanto, esse instituto do condomínio edilício, regulado pelo Código Civil de 2002, destacando-se o artigo $6^{\circ}$ da Lei ${ }^{\circ}$ 4.5691/64: "Sem prejuízo do disposto nesta Lei, regular-se-á pelas disposições de direito comum o condomínio por quota ideal de mais de uma pessoa sobre a mesma unidade autônoma.". Dois aspectos interessantes devem ser postos: primeiro, a citada regra está em vigor, já que não há tipo correspondente no Código Civil atual; segundo, a possibilidade, no Direito brasileiro, de mais de uma pessoa ser detentor de uma unidade autônoma, um dos pilares da multipropriedade (STAFFEN, 2011) ${ }^{7}$.

Em setembro de 2016, o STJ demonstrou a complexidade teórica/fática de caso envolvendo a multipropriedade no Resp $n^{\circ} 1.546 .165$-SP, cujo julgamento abordou o conflito entre duas teorias sobre a natureza jurídica do instituto no Direito brasileiro. O ministro Ricardo Villas Bôas Cueva, em seu voto, defendeu: "Trata-se de situação jurídica complexa e atípica que en-

7 Ao analisar a questão Rodrigues e Marques (2010, p. 418) ponderam: “Algumas considerações são necessárias para serem feitas no tocante a distinção entre condomínio e a multipropriedade. No condomínio, uma mesma coisa pertence simultaneamente a diversas pessoas, e os seus titulares terão o direito de usar e gozar do bem na parte comum a todos e poderão inclusive, dispor do bem na medida da sua fração ideal. Por sua vez, na multipropriedade, os seus titulares não podem fruir do seu direito ao mesmo tempo em que os outros, sendo necessário que se estabeleça qual o período que cada um gozará do seu domínio amplo e irrestrito na propriedade.”. 
volve relações obrigacionais específicas interligadas por diversas fontes de interesses - os multiproprietários entre si, e entre estes e a administração do empreendimento - em colaboração recíproca para a satisfação na utilização do bem.”.

Clara a conclusão do julgador de que o time sharing é direito pessoal, já que se trata de contrato regulando condutas de propriedade pertencente a terceiros. Ocorre que seu voto foi vencido e prevaleceu o entendimento do ministro João Otávio de Noronha, cujas conclusões podem ser destacadas:

\footnotetext{
O registro de instrumento particular de promessa de cessão de direitos, por exemplo, que conste o regime da multipropriedade, pode ser considerando um direito real de aquisição (artigos. 1.417 e 1.418 do Código Civil)

\begin{abstract}
A natureza jurídica da multipropriedade, considerando o instituto da propriedade, é compatível com um direito real, não existindo qualquer vedação expressa do código civil ou de qualquer outra legislação aplicável à espécie.
\end{abstract}

As faculdades da propriedade se harmonizam com o instituto da multipropriedade, considerando o uso em turnos fixos de tempo".

Interessante ressaltar que o condomínio edilício ou horizontal já seria caracterizado como um condomínio especial, considerando-se a questão das áreas comuns e das áreas privativas, tendo inclusive garantido capítulo específico no Código Civil brasileiro, mas a multipropriedade, conforme o visto, teria outra especificidade, consistente na copropriedade sobre uma mesma unidade com exclusividade num determinado lapso de tempo.

Tal aspecto, conforme visto no voto vencedor, em face da inexistência de legislação específica, não afasta a possiblidade de se conferir ao instituto, mesmo com suas peculiaridades, a natureza de condomínio edilício, caso o empreendimento seja dividido em frações ideais do terreno para cada multiproprietário. Em síntese, o diagnóstico da natureza jurídica da multipropriedade (acionária, real ou obrigacional) depende de como é organizada.

Ponto específico a se ressaltar nesta fase do artigo é que a multipropriedade é presente no Brasil e sua organização como Direito Real não pode ser descartada, pois se assemelharia a um condomínio edilício ${ }^{8}$, sobre o qual o multiproprietário possui as faculdades da propriedade de forma exclusiva, mesmo em um determinado espaço de tempo, não servindo a citada limitação para excluir o instituto em análise como um tipo de propriedade, respeitando-se o dogma do numerus clausus aceito no Direito brasileiro, que tem como objetivo eliminar a livre criação dos Direitos Reais, evitando-se a insegurança jurídica dos negócios imobiliários.

A natureza jurídica do instituto em tela, observando o direito comparado, está longe de se constituir um consenso. Fazano (2003, p. 123), na sua obra, relata que a legislação Portuguesa trata a multipropriedade como direito real de uso, enquanto que na Argentina e Venezuela referese a ela como uma propriedade de tempo compartilhado.

Conforme já exposto, a tese que vem ganhando corpo nos Tribunais pátrios consiste em considerar a multipropriedade uma espécie de condomínio, o que viabilizaria o entendimento de

8 Vide sobre o assunto: I Jornada de Direito Civil - Enunciado 89: "O disposto nos arts. 1.331 a 1.358 do novo Código Civil aplica-se, no que couber, aos condomínios assemelhados, tais como loteamentos fechados, multipropriedade imobiliária e clubes de campo.”. (http://www.cjf.jus.br/enunciados/pesquisa/resultado). 
que se trata de propriedade típica, consequentemente, de Direito Real ${ }^{9}$. Tal entendimento é essencial ao se julgar questões que tenham como causa de pedir cobrança de quota condominial, penhora e aquisição ou perda da multipropriedade, por exemplo.

Esclarece-se que o cerne da pesquisa não é encerrar o assunto multipropriedade ou continuar com as antigas discussões sobre a aplicação ou flexibilização da teoria do numerus clausus (MELO, 2011), mas responder se o multiproprietário pode perder seu direito de uso, gozo, disponibilidade e reivindicação pela ocorrência da prescrição aquisitiva.

\section{O InSTITUTO da USUCAPIÃO NO DiREITO BRASILEIRO: ALGUMAS NOTAS}

A propriedade, além de significar um direito para o seu titular, a ser garantido pelo Estado e respeitado pelos particulares, abrange deveres, cuja desobediência implica o não cumprimento da sua função social ou econômica. A propriedade então, ante esses novos elementos, obriga.

A aquisição da propriedade pode ser classificada, citando-se Justo (2007, p. 252), em originária, cujo direito "surge 'ex novo' com base no contato imediato com a coisa e na total independência de alguma relação jurídica que eventualmente ligue o proprietário adquirente a outro sujeito" ou derivada, na qual o direito do novo proprietário deriva do antigo mediante uma relação jurídica idônea.

No sistema jurídico adotado pelo Código Civil brasileiro, a aquisição da propriedade imobiliária se dá por: a) usucapião (forma originária - artigos 1.238 a 1.247); b) registro de título (derivada - artigos 1.245 a 1.247); e c) aquisição por acessão (originária - artigos 1.248 a 1.259), sendo a usucapião o tipo de aquisição originária em análise no presente artigo.

A usucapião, por aspecto lógico, não é apenas forma de aquisição da propriedade, mas também de perda para aquele que não exerceu seu direito à posse. No Direito Romano, desde o período arcaico (753 a.C. a 130 a.C.) já se tinha regramento importante sobre essa matéria com o surgimento, por volta de 449 a.C., da Lei das XII Tábuas, importante legislação das relações humanas e patrimoniais na Roma Republicana.

Na Tábua VI, conforme exposto em Siqueira (2012), nota-se a preocupação das normas com a aquisição da coisa. Num determinado item estabelecia a usucapião após dois anos de posse. O mesmo ocorre na Tábua V, que segundo anotação de Gaio ${ }^{10}$, tratava primordialmente dos aspectos sucessórios, e proibia a ocorrência de usucapião de res mancipi pertencentes à mulher tutelada pelos seus agnados.

O instituto da usucapião, pela importância, atravessou a história brasileira, presente nas Ordenações do Reino, destacando-se o Livro II, Títulos 26 (direitos reais) e 27 (dos forais e determinações, onde se estabelece direitos a posse imemorial) e o Livro IV, Título 79 (das prescrições), ambos das Ordenações Filipinas, vigentes no Brasil dos séculos XVII ao XX.

9 Em outubro de 2017 foi aprovado o projeto de lei 7.553/2017 na comissão de Constituição e Justiça e de cidadania da Câmara dos Deputados, cuja redação acrescenta o inciso XIV ao artigo 1.225 do Código Civil, tornando a multipropriedade um direito real. Em 07/11/2017 o projeto se encontrava na Mesa Diretora da Câmara dos Deputados, não tendo sido apresentado recursos.

${ }^{10}$ Gaio foi um jurisconsulto romano que, por volta do ano de 161 d.C., editou um manual de Direito Romano com informações valiosas sobre o Direito Romano clássico, servindo de base para o Corpus Iuris Civilis. 
Tabela 3 - Comparativo entre os Códigos Civis de 2002 e 1916

\begin{tabular}{|c|c|}
\hline CÓDIGO DE 2002 & CÓDIGO DE 1916 \\
\hline $\begin{array}{l}\text { Usucapião independente de título e boa-fé => } \\
\text { prazo } 15 \text { anos, sem interrupção e oposição (artigo } \\
\text { 1.238), podendo ser reduzido para dez anos se o } \\
\text { possuidor houver estabelecido no imóvel sua mo- } \\
\text { radia habitual ou realizado obras ou serviço de ca- } \\
\text { ráter produtivo. Nominado pela doutrina de usuca- } \\
\text { pião extraordinário }\end{array}$ & $\begin{array}{l}\text { Usucapião independente de título e boa- } \\
\text { fé => prazo } 20 \text { anos (artigo } 550 \text { ), não } \\
\text { existindo regra para sua redução. }\end{array}$ \\
\hline $\begin{array}{l}\text { Usucapião com justo título e boa-fé=> prazo } 10 \\
\text { anos, contínuos e incontestáveis (artigo 1.242), re- } \\
\text { dutível para cinco anos se o imóvel houver sido } \\
\text { adquirido onerosamente, com base no registro do } \\
\text { respectivo cartório, cancelada posteriormente, } \\
\text { desde que os possuidores nele tiverem estabele- } \\
\text { cido sua moradia ou realizado investimentos de in- } \\
\text { teresse social e econômico. Denominado pela dou- } \\
\text { trina de usucapião ordinária. }\end{array}$ & $\begin{array}{l}\text { Usucapião com justo título e boa-fé=> } \\
\text { prazo } 10 \text { anos entre presentes (morado- } \\
\text { res do mesmo município), ou } 15 \text { anos } \\
\text { entre ausentes (moradores de municí- } \\
\text { pios diversos), contínuo e inconteste, } \\
\text { não existindo regra para sua redução (ar- } \\
\text { tigo 551). Denominada pela doutrina de } \\
\text { usucapião ordinária. }\end{array}$ \\
\hline
\end{tabular}

Usucapião de imóvel em área urbana de até $250 \mathrm{~m}^{2}$ $\Rightarrow$ prazo 5 anos ininterruptos e sem oposição, com requisitos de que não seja proprietário de outro imóvel urbano ou rural e que o bem sirva para sua moradia. $\mathrm{O}$ benefício não será concedido mais de uma vez (artigo 1.240).

A redação deste artigo está em conformidade com o artigo 183 da CF de 1988, que acrescenta a norma impeditiva de usucapião de bens públicos.

$\mathrm{Na}$ questão de contagem do tempo exigido para a prescrição aquisitiva é possível ao autor do procedimento acrescentar a sua posse a dos seus antecessores, contanto que todas sejam contínuas, pacíficas e, nos casos da usucapião ordinária, com justo título e de boa-fé (artigo 1.243).

As causas constantes no Código Civil que suspendem ou interrompem a prescrição do devedor também se aplicam à usucapião (artigo 1.244).

Sem correspondente no Código de 1916.

Usucapião familiar => prazo 2 anos com posse exclusiva, ininterrupta e sem oposição de imóvel com até 250 metros, cuja propriedade era dividida com ex-cônjuge ou ex-companheiro que abandonou o lar. Como requisitos a norma acrescentada pela Lei $\mathrm{n}^{\circ} 12.424 / 2011$ determina que o bem seja utilizado para moradia do beneficiário ou de sua família, não podendo este ser proprietário de outro imóvel urbano ou rural (artigo 1.240A)

Fonte: elaboração própria dos autores 
O Código Civil brasileiro de 2012 em relação ao Código anterior, tendo por base a propriedade imobiliária urbana, continua a adotar, não de forma exclusiva, a teoria objetiva defendida desde o século XIX por Ihering ${ }^{11}$, concedendo ao animus escasso valor para explicar a posse usucapienda (vide artigo 1.196 do Código civil de 2012), mas inova ao reduzir os prazos prescricionais da usucapião ordinária e extraordinária, estabelecer novos tipos de usucapião e tratar da usucapião de imóvel urbano com área reduzida, já tipificada pela Constituição de 1988. Para ilustrar o exposto apresenta-se a Tabela 1:

Para além dos Códigos brasileiros apresentados na Tabela 1, importa também destacar, no campo da usucapião de imóvel urbano, o Estatuto da cidade (Lei no 10.257/2001, anterior ao Código Civil de 2002 $2^{12}$, que inscreve a usucapião especial em seu artigo $9^{\circ}$, apresentando características semelhantes à usucapião abordada no artigo 183 da Constituição Federal e posteriormente no artigo 1.240 do Código Civil vigente. Já a usucapião especial comunitária regulada pelo artigo 10 constituiu importante inovação no Direito pátrio ao permitir a usucapião coletiva, que tem como requisitos: a) áreas urbanas com área superior a $250 \mathrm{~m} 2$; b) posse coletiva por população de baixa renda; c) prazo de cinco anos ininterrupto e sem oposição, sendo possível, para o fim de contar o prazo exigido pelo artigo, acrescentar sua posse à de seu antecessor, contanto que ambas sejam contínuas; d) impossibilidade de os possuidores terem outra propriedade imobiliária, urbana ou rural.

${ }^{11}$ Rudolf von Ihering (Aurich, 22 de agosto de 1818 - Gotinga, 17 de setembro de 1892) foi um jurista alemão. Ocupa ao lado de Friedrich Karl von Savigny lugar ímpar na história do Direito alemão, tendo sua obra influenciado significativamente a cultura jurídica em todo o mundo ocidental (RUDOLF..., 2017).

12 Sobre a questão da usucapião urbana e seus requisitos propostos pelo Código Civil vide os seguintes enunciados das jornadas de Direito civil promovidas pelo Conselho da Justiça Federal até 2017: I Jornada de Direito Civil - Enunciado 85: "Para efeitos do art. 1.240, caput, do novo Código Civil, entende-se por 'área urbana' o imóvel edificado ou não, inclusive unidades autônomas vinculadas a condomínios edilícios."; I Jornada de Direito Civil - Enunciado 86: "A expressão ‘justo título' contida nos arts. 1.242 e 1.260 do Código Civil abrange todo e qualquer ato jurídico hábil, em tese, a transferir a propriedade, independentemente de registro."; III Jornada de Direito Civil - Enunciado 251: "O prazo máximo para a usucapião extraordinária de servidões deve ser de 15 anos, em conformidade com o sistema geral de usucapião previsto no Código Civil."; IV Jornada de Direito Civil - Enunciado 302: "Pode ser considerado justo título para a posse de boa-fé o ato jurídico capaz de transmitir a posse ad usucapionem, observado o disposto no art. 113 do Código Civil.”; IV Jornada de Direito Civil - Enunciado 303: "Considera-se justo título, para a presunção relativa da boa-fé do possuidor, o justo motivo que lhe autoriza a aquisição derivada da posse, esteja ou não materializado em instrumento público ou particular. Compreensão na perspectiva da função social da posse.”; IV Jornada de Direito Civil - Enunciado 313: "Quando a posse ocorre sobre área superior aos limites legais, não é possível a aquisição pela via da usucapião especial, ainda que o pedido restrinja a dimensão do que se quer usucapir.”; IV Jornada de Direito Civil - Enunciado 315: "O art. 1.241 do Código Civil permite ao possuidor que figurar como réu em ação reivindicatória ou possessória formular pedido contraposto e postular ao juiz seja declarada adquirida, mediante usucapião, a propriedade imóvel, valendo a sentença como instrumento para registro imobiliário, ressalvados eventuais interesses de confinantes e terceiros.”; V Jornada de Direito Civil - Enunciado 497: "O prazo, na ação de usucapião, pode ser completado no curso do processo, ressalvadas as hipóteses de má-fé processual do autor.”; V Jornada de Direito Civil - Enunciado 498: "A fluência do prazo de 2 (dois) anos previsto pelo art. 1.240-A para a nova modalidade de usucapião nele contemplada tem início com a entrada em vigor da Lei n. 12.424/2011.”; V Jornada de Direito Civil - Enunciado 500: "A modalidade de usucapião prevista no art. 1.240-A do Código Civil pressupõe a propriedade comum do casal e compreende todas as formas de família ou entidades familiares, inclusive homoafetivas."; VI Jornada de Direito Civil - Enunciado 564: “As normas relativas à usucapião extraordinária (art. 1.238, caput, CC) e à usucapião ordinária (art. 1.242, caput, CC), por estabelecerem redução de prazo em benefício do possuidor, têm aplicação imediata, não incidindo o disposto no art. 2.028 do Código Civil.”; VI Jornada de Direito Civil - Enunciado 569: "No caso do art. 1.242, parágrafo único, a usucapião, como matéria de defesa, prescinde do ajuizamento da ação de usucapião, visto que, nessa hipótese, o usucapiente já é o titular do imóvel no registro.”; VII Jornada de Direito Civil - Enunciado 595: "O requisito 'abandono do lar' deve ser interpretado na ótica do instituto da usucapião familiar como abandono voluntário da posse do imóvel somado à ausência da tutela da família, não importando em averiguação da culpa pelo fim do casamento ou união estável. Revogado o Enunciado 499."; VII Jornada de Direito Civil - Enunciado 596: "O condomínio edilício pode adquirir imóvel por usucapião.”. (http://www.cjf.jus.br/enunciados/pesquisa/ resultado). 
$\mathrm{O}$ aspecto interessante de natureza adjetiva é que a sentença na usucapião coletiva que servirá de título para registro no cartório competente (artigo $10^{\circ}, \S \S 3^{\circ}$ e $4^{\circ}$ ) estabelecerá um condomínio, que só poderá ser extinto por decisão de no mínimo 2/3 dos condôminos. Em síntese, em face da indivisibilidade originária do próprio bem, o juiz atribuirá igual fração ideal de terreno a cada possuidor, independentemente da dimensão do terreno que cada um ocupe, salvo hipótese de acordo escrito entre os condôminos estabelecendo frações ideais diferenciadas.

Conforme o visto, a usucapião como forma aquisitiva da propriedade imobiliária urbana necessita de procedimento próprio, anteriormente de índole exclusivamente judicial, sendo a sentença proferida pelo juiz de natureza eminentemente declaratória, isto é, apta a reconhecer a aquisição da propriedade obtida pelo transcurso do prazo, respeitados os requisitos de cada caso.

A matéria tratada neste tópico, objeto de estudo tanto do Direito Civil como do Processo Civil, sofreu importante alteração, já que a Lei no 13.105/2015 (Novo Código de Processo Civil) deixa de regular o tópico como procedimento especial, com regras bem específicas, a exemplo da citação da Fazenda Pública, tornando-o procedimento comum. Outra inovação processual é a possibilidade da usucapião administrativa, processada perante Cartório de Registro de Imóveis em moldes similares à retificação imobiliária administrativa. O artigo 1.071 do Código cria o artigo 216A da Lei $\mathrm{n}^{\circ}$ 6.015/73 tornando-a faculdade do adquirente, que deve arcar com as custas cartoriais e ser representado por advogado. A rejeição do pedido administrativo não faz coisa julgada, permitindo o ajuizamento da ação no juízo competente.

$\mathrm{O}$ fato de passar a ser procedimento comum não modifica o entendimento de que a pessoa em cujo nome se encontra registrado o bem e os confinantes devem ser citados (artigo 246, $\S 3^{\circ}$, do NCPC), mas abre-se um questionamento acerca da necessidade de intimação das fazendas públicas e da intervenção obrigatória do Ministério Público. Não resta dúvida da sua complexidade, pois no procedimento comum esses chamamentos não são obrigatórios em todos os casos de usucapião tratados anteriormente pelos artigos 943 e 944 do CPC de 1973.

Acerca da atuação do Ministério Público, defende-se que será chamado apenas nos casos do artigo 178 do NCPC (envolvimento de: I - interesse público ou social; II - interesse de incapaz; III - litígios coletivos pela posse de terra rural ou urbana), como por exemplo, usucapião coletivo, ou em outros casos especiais, previamente previstos em lei extravagante.

A intimação das Fazendas Públicas é assunto delicado, sobre o qual o NCPC silencia por completo, tendo determinado, no entanto, ao regular a usucapião administrativa perante o Registro de Imóveis em seu artigo 1.071, a ciência da União, do Estado, do Município e do Distrito Federal, se for o caso, para no prazo de 15 dias manifestarem interesse. Essa determinação faz concluir que tal procedimento também é aplicável ao procedimento judicial, pois a finalidade buscada pela lei é a mesma, sendo impensável que no procedimento administrativo, que pode vir a se transformar em judicial, é necessária a notificação das Fazendas Públicas e no procedimento judicial não (ARAÚJO, 2015).

Outras duas notas importantes sobre a aquisição da propriedade por usucapião são: a) a jurisprudência (STJ. REsp n $\left.{ }^{\circ} 1.088 .082 / R J\right)$, com fundamento no artigo 493 do NCPC, que mantém semelhança com o artigo 462 do CPC de 1973, vem aceitando que não constitui caso de improcedência da ação o fato de que o prazo da posse venha a se completar apenas durante a ação, já que o juiz deve levar em consideração qualquer fato constitutivo, modificativo ou extintivo do direito que tenha influência no julgamento do mérito, devendo os outros requisitos serem comprovados; b) não cabe procedimento arbitral em matéria de usucapião por dois motivos: I. a convenção de arbitragem (compromisso ou cláusula compromissória cheia) deve ser firmada por todas as partes envolvidas, sendo que na ação de usucapião sempre terá que existir a citação por edital dos réus incertos (possíveis interessados - artigo 259 do NCPC), o que, por si só, de forma 
lógica, inviabiliza a convenção prévia; II. a notificação das Fazendas Públicas e a possível manifestação de interesse de uma delas implica a impossibilidade de estabelecimento de compromisso, pelo fato de a matéria (bem público ocupado por particular que alega usucapião) ser direitos patrimoniais indisponíveis, fato vedado pelo artigo $1^{\circ}, \S 1^{\circ}$, da Lei Federal $n^{\circ}$ 9.307/96, modificada pela Lei no 13.129/2015, que abriu o procedimento arbitral à Administração Pública.

Apresentados alguns pontos relevantes sobre a usucapião no Direito brasileiro, retornase à questão central deste artigo, a possibilidade da aquisição ou perda de direito a multipropriedade por usucapião considerando-se as especificidades tratadas no tópico 2, devendo ser observadas a função social da posse e a natureza jurídica de como foi organizado o time sharing.

\section{Usucapião, Posse, FunÇão Social e Multipropriedade: ASPECTO Aquisitivo}

A aquisição da propriedade por usucapião tem como seu principal requisito a posse por determinado espaço de tempo, que não pode ser violenta, clandestina ou precária, não deixando de ser uma consolidação de direitos, já que a pessoa que a obtém e exerce passa a ter a propriedade, elevando seu grau de direito sobre a coisa, em conformidade com a teoria da propriedade privada e suas faculdades de usar, gozar, dispor e reivindicar.

Em sua defesa pode-se recorrer ao princípio da função social (GRAU, 2007), pois a posse originária ou derivada capaz de levar a esse tipo de aquisição da propriedade deve ser justa, isto é, segundo Salles (2005), escoimada de violência (obtida pela força), clandestinidade (obtida ocultamente) ou precariedade (obtida por abuso de confiança, tendo se obrigado a restituir a coisa). É interessante ressaltar que a posse pode até ter sido obtida, por exemplo, com violência, mas quando cessa, o prazo aquisitivo inicia seu curso normal, devendo ser contínuo até o seu termo final. Ora, se o direito de propriedade deve ser exercido em conformidade com a função social da propriedade, a posse, como um dos seus elementos exteriorizadores, ou o seu exercício deve guardar também obediência ao citado princípio.

A função social ${ }^{13}$ da posse é reconhecida pela doutrina (ZAVASCKI, 2003) e jurisprudência ( $R E n^{\circ}$ 422.349/RS, Relator(a): Min. Dias Toffoli) brasileiras, e não resta dúvida de que está relacionada com o princípio da função social da propriedade, pois a posse, como elemento exteriorizador da primeira, desprovida de função social tornar-se-ia um absurdo jurídico, tendo como referência o Código Civil, artigo $1.228, \S 1^{\circ}$ e a Constituição Federal, artigo $5^{\circ}$, inciso XXIII. Ilustrando o exposto Zavascki (2003, p.51) afirma: "Bem se vê, destarte, que o princípio da função social diz respeito mais ao fenômeno possessório que ao direito de propriedade. Referida função 'é mais evidente na posse e muito menos na propriedade', observa a doutrina atenta, e daí falar-se em função social da posse.”.

Mesmo tratadas de forma autônoma, em face das diferenças entre o instituto da posse e da propriedade pode-se defender que o princípio, prima facie, aplica-se quando se está a analisar tanto a posse quanto a propriedade. É digno de nota que a observação da função social da posse no Direito brasileiro vem sendo explicada até na defesa, por exemplo, da possibilidade de desapropriação de imóvel rural produtivo caso o fracionamento da terra para demanda da reforma agrária se mostre mais útil que a manutenção do latifúndio em exploração por um único produtor. Logo a proteção da propriedade ou da posse não se liga tão somente a aspectos de produtividade

${ }^{13}$ Sobre essa questão ver Damacena e Webber (2016, p.58). 
econômica, como faz crer a Constituição e o próprio Código Civil (função social e função econômica, artigo 1.228, § $1^{\circ}$ ) (BERCOVICI, 2015).

Não resta dúvida de que a posse do imóvel por outrem, distinto do proprietário, com os requisitos legais que possibilitam a aquisição por usucapião e ainda mais com animus domini, leva à constatação do desinteresse do seu antigo possuidor/proprietário, que não está a cumprir com o princípio da função social da posse. Complementando-se esta análise expõem-se: a) o não aproveitamento da coisa pelo antigo detentor caracteriza infração ao princípio da função social, pois a falta da posse, direta e indireta, por ato volitivo, denota falta de exercício das faculdades imanentes a posse e propriedades, sancionada com a própria perda do domínio; b) a posse justa exercida pelo usucapiente denota uso e gozo, isto é, aproveitamento de bem imóvel tutelado e garantido pelo ordenamento jurídico por sua importância na questão social e produtiva da sociedade, sendo possível inclusive a redução do lapso temporal em conformidade com os artigos 1.238 e 1.242, ambos do Código Civil de 2002.

Feita a ligação entre a função social da posse e a aquisição da propriedade pela usucapião, retorna-se ao questionamento acerca da aquisição de imóvel organizado sob o regime do time sharing por usucapião. No primeiro tópico deste artigo observaram-se algumas características da multipropriedade, como a temporariedade da posse, a forma de sua organização e a questão da natureza do instituto como sendo de Direito Real ou não.

Naquela ocasião concluiu-se que apesar de a exclusividade da posse/propriedade ser limitada a um determinado espaço de tempo, sua caracterização como Direito Real depende da forma de sua organização (acionária, real ou obrigacional), isto é, de como é formado o time sharing. A questão é lógica, pois, ao se concluir que a relação advinda da denominada multipropriedade é acionária ou obrigacional, não há qualquer sentido em se falar de aquisição de propriedade quando não há propriedade ou Direito Real sobre a coisa em tela.

Não constitui ambição de um artigo científico com limitações de páginas, que trata de aquisição de propriedade, conceituar Direito Real, propriedade ou suas formas de aquisição. Mas para se entender se a multipropriedade constitui um Direito Real, deve-se analisar as características deste. Tanto a doutrina italiana, aqui representada por Caringella (2014), como a brasileira, ilustrada por Gomes (2008), e a portuguesa, na pessoa de Justo (2007), consideram a aplicação da teoria do numerus clausus ao Direito Real e tratam como sua característica, com algumas variações terminológicas e em caráter não exaustivo, o caráter absoluto do seu exercício, expresso no direito de se fazer valer erga omnes, criando, para Caringella (2014), uma obrigação negativa: não turbar a exclusividade desta relação (pessoa - coisa). Para Justo (2007), essa peculiaridade é uma das razões determinantes do princípio da tipicidade ou numerus clausus. A segunda característica seria o imediatismo, já que o direito é exercido de forma direta, sem a necessidade de outra parte, como no Direito Obrigacional. Já a terceira seria a da pertinência ou inerência, que traduz a ligação ou incorporação dos Direitos Reais às coisas. Cordeiro (1993, p. 328) fala que a inerência " [...] filia-se directamente no facto de, no direito real, se realizar a afectação de uma coisa corpórea”.

A multipropriedade no Brasil, conforme visto no tópico 2, não possui legislação própria a regulá-la, existindo no Direito brasileiro controvérsia acerca da sua natureza jurídica (Direito Pessoal ou Direito Real). O que deve ficar claro, ante a inexistência de regra específica, é que se a propriedade edificada for registrada em nome de várias pessoas com direito ao exercício das suas faculdades em caráter absoluto, imediato e inerente, mesmo por um espaço de tempo previamente determinado numa convenção, estar-se-á diante de um condomínio edilício de natureza especial, regulado no Título III (Da Propriedade) do Livro III (Do Direito das Coisas) do Código vigente, constituindo, portanto, um Direito Real. 
Acerca do assunto, Caringella (2014, p. 245) atesta:

Secondo una prima tesi, in un'ottica di superamento del principio del numerus clausus dei diritti reali, la mutiproprietà costituirebbe un diritto reale atipico, caratterizzato dal fatto che il godimento sul bene presenta il carattere dell'intermittenza.

A natureza é especial ou atípica, pois as unidades autônomas do condomínio edilício possuem vários detentores de direito, sendo as faculdades da propriedade limitadas não só pelos elementos restritivos da Constituição, Lei ou contratos, mas pelo aspecto temporal, isto é, pelo fato de que o gozo do bem é caracterizado pela intermitência previamente acertada entre os interessados. O interessante é que durante o prazo de posse direta todas as características e faculdades da propriedade estarão à disposição do seu titular. Acrescenta-se que esse é o entendimento do voto vencedor do ministro do Superior Tribunal de Justiça João Otávio de Noronha no REsp $\mathrm{n}^{\mathrm{o}}$ 1.546.165-SP.

Ora, se a conclusão é que a multipropriedade seria uma espécie de condomínio edilício e que, segundo Caringella (2014, p. 244), "Il diritto del multiproprietario, sull'immobile è transmissibile inter vivos e causa mortis", expõe-se que podem ser-lhe aplicadas as regras inerentes àquele instituto, não restando dúvidas de que as formas de aquisição e perda desse tipo de propriedade podem e devem ser aplicadas, entre elas a usucapião ${ }^{14}$.

Uma das consequências dessa conclusão é que a não utilização da posse no espaço de tempo destinado à sua fruição poderá levar o multiproprietário à perda de seu Direito Real em benefício de outrem, que passa a adquiri-la, se o substituir na posse durante o prazo assinalado no Código Civil. Ressalta-se que a posse do adquirente não poderá ser violenta, clandestina e precária e deve ocorrer sempre no lapso temporal destinado pela convenção à fruição do multiproprietário omisso.

Por outro lado, caso o empreendimento imobiliário seja registrado em nome de uma pessoa jurídica, que confere direitos possessórios temporários de unidade autônoma a particulares por intermédio de contratos, constitui uma espécie de time sharing com característica de Direito Pessoal/locacional (multipropriedade obrigacional ${ }^{15}$ ), não tendo sentido em se falar de aquisição de direitos por usucapião, já que a posse direta, nesse caso, seria precária e derivada de negócio jurídico prévio.

Em síntese, a multipropriedade real, considerando-se as espécies de multipropriedade citadas pela doutrina consultada, listada nas referências, permite a perda dos direitos reais do multiproprietário por usucapião, mediante procedimento judicial ou extrajudicial, desde que provados os requisitos postos no Código Civil e no Código de Processo civil anotados pontualmente no tópico 3 deste artigo.

Deixa-se claro que o fato gerador para a caracterização da usucapião, seja ordinário ou extraordinário ou especial, é a não fruição da posse por um dos multiproprietários no período destinado a este, passando o possuidor neste período a comprovar seu uso e requerer a usucapião

${ }^{14}$ Caringella (2014) menciona também o Código do Turismo de 2011, que modificou a disciplina da multipropriedade ao estabelecer regras acerca da duração do contrato que a regulamenta, inscrevendo novos elementos acerca de sua natureza como sendo um negócio jurídico.

15 Sobre as espécies de multipropriedade, especificamente a obrigacional, ver Melo (2011, p. 25): "Parece-nos que a multipropriedade obrigacional - cuja denominação já seria um paradoxo, uma vez que, existindo o caráter pessoal, não poderia ser propriedade ou direito real - está fortemente ligada à sua própria origem, decorrente do contrato de locação e não é satisfatória ao usuário em razão do próprio esvaziamento de conteúdo real necessário para a outorga de relativa segurança aos detentores do direito. Restringir os problemas inerentes à mera indenização é medida das menos relevantes quando estamos defendendo a utilização de um instituto criado para satisfazer uma necessidade básica do ser humano que é o lazer.”. 
caso comprove os requisitos, tendo por base apenas os períodos destinados a pessoa que perdeu o direito.

Aspecto digno de nota é que a ação de usucapião, em caso de multipropriedade imobiliária ou real, interposta pelo possuidor de uma unidade que comprova o uso no espaço temporal destinado a outrem, no entendimento destes pesquisadores, não deve ser ajuizada contra o grupo ou contra o condomínio, sendo o único legitimado para compor o polo passivo, em conjunto com os confinantes e os réus incertos, a pessoa que deixou de exercer seu direito no espaço de tempo conferido ao exercício de suas faculdades.

\section{CONCLUSÃo}

As conclusões obtidas com a pesquisa, que trata da aquisição da multipropriedade imobiliária urbana por usucapião, expostas neste artigo ao longo dos tópicos construídos, podem ser sintetizadas nos seguintes pontos:

A multipropriedade é presente no Brasil, como se pode observar nas decisões judiciais citadas neste trabalho, e sua organização como Direito Real não pode ser descartada, pois se assemelharia a um condomínio edilício, sobre o qual o multiproprietário possui as faculdades da propriedade de forma exclusiva, mesmo em um determinado espaço de tempo, limitação inservível para excluir o citado instituto como um tipo de propriedade, respeitando-se o dogma do numerus clausus aceito no Direito brasileiro.

A usucapião como forma aquisitiva da propriedade imobiliária urbana necessita de procedimento próprio, anteriormente de índole exclusivamente judicial, sendo a sentença proferida pelo juiz de natureza eminentemente declaratória, isto é, apta a reconhecer a aquisição da propriedade obtida pelo transcurso do prazo, respeitados os requisitos de cada caso.

Não resta dúvida de que a posse do imóvel por outrem, distinto do proprietário, com os requisitos legais que possibilitam a aquisição por usucapião e ainda mais com animus domini, leva à constatação do desinteresse do seu antigo possuidor/proprietário, que não está a cumprir com o princípio da função social da posse. Complementando-se esta análise expõem-se: a) o não aproveitamento da coisa pelo antigo detentor caracteriza infração ao princípio da função social, pois a falta da posse, direta e indireta, por ato volitivo, denota falta de exercício das faculdades imanentes a posse e propriedades, sancionada com a própria perda do domínio; b) a posse justa exercida pelo usucapiente denota uso e gozo, isto é, aproveitamento de bem imóvel tutelado e garantido pelo ordenamento jurídico por sua importância na questão social e produtiva da sociedade, sendo possível inclusive a redução do lapso temporal em conformidade com os artigos 1.238 e 1.242, ambos do Código Civil de 2002.

A multipropriedade no Brasil, conforme visto no tópico 2, não possui legislação própria a regulá-la, existindo no Direito brasileiro controvérsia acerca da sua natureza jurídica (Direito Pessoal ou Direito Real). O que deve ficar claro, ante a inexistência de regra específica, é que se a propriedade edificada for registrada em nome de várias pessoas com direito ao exercício das suas faculdades em caráter absoluto, imediato e inerente, mesmo por um espaço de tempo previamente determinado numa convenção, estar-se-á diante de um condomínio edilício de natureza especial, regulado no Título III (Da Propriedade) do Livro III (Do Direito das Coisas) do Código vigente, constituindo, portanto, um Direito Real.

A não utilização da posse no espaço de tempo destinado à sua fruição poderá levar o multiproprietário à perda de seu Direito Real em benefício de outrem, que passa a adquiri-la, se o substituir na posse durante o prazo assinalado no Código Civil. Ressalta-se que a posse do 
adquirente não poderá ser violenta, clandestina e precária e deve ocorrer sempre no lapso temporal destinado pela convenção à fruição do multiproprietário omisso.

\section{REFERÊNCIAS}

ALPA, Guido. Che cos'è Il diritto privato? Roma: Laterza, 2007.

ARAÚJO, Fábio Caldas de. Usucapião. 3. ed. São Paulo: Malheiros, 2015.

BERCOVICI, Gilberto. Propriedade que descumpre função social não tem proteção constitucional. Conjur, 6 dez. 2015. Disponível em: <http://www.conjur.com.br/2015-dez-06/estado-economia-propriedade-nao-cumpre-funcao-social-nao-protecao-constitucional>. Acesso em: 15 maio 2017.

CARINGELLA, Francesco. Manuale di Diritto Civile. diritti reali. Roma: Dike, 2014. V.1.

CORDEIRO, Antônio Menezes. Direitos reais. 19. ed. Lisboa: Lex, 1993.

DAMACENA, Fernanda Dalla Libera; WEBBER, Suelen. O direito de propriedade e a supremacia do interesse público sobre o privado na era de adaptação às mudanças climáticas. Revista Jurídica da UNI7, Fortaleza, v. 13, n. 2, p. 55-70. 2016. Disponível em: http://www.uni7setembro.edu.br/periodicos/index.php/revistajuridica/issue/view/17

FAZANO, Haroldo Guilherme Vieira. Da propriedade horizontal e vertical. Campinas: Lex editora, 2003.

GOMES, Orlando. Direitos reais. 19. ed., 7. tiragem, revista, atualizada e aumentada por Luiz Edson Fachin. Rio de Janeiro: Forense, 2008.

GRAU, Eros Roberto. A ordem econômica na Constituição de 1988. São Paulo: Malheiros, 2007.

JUSTO, Antonio dos Santos. Direitos reais. Coimbra: Coimbra editora, 2007.

MELO, Marcelo Augusto Santana de. Multipropriedade imobiliária. Revista de Direito Imobiliário, v. 70, ano 34, p. 19-80, jan./jun. 2011.

MULTIPROPRIEDADE - time-sharing é direito real? Círculo Registral Imobiliário, 7 set. 2016. Disponível em: <https://circuloregistral.com.br/2016/09/07/multipropriedade-time-sharing-e-direito-real/>. Acesso em: 15 jan. 2017.

PEREIRA, Caio Mário da Silva. Condomínio e incorporações. Atualizado pr Sylvio Capanema de Sousa e Melhim Namem Chalhub. Rio de Janeiro: Forense, 2014.

RODRIGUES, Francisco Luciano Lima; MARQUES, Hérika Janaynna Bezerra de M. M. Notas a respeito da multipropriedade imobiliária como nova modalidade do exercício do direito de propriedade. Pensar, Fortaleza, v. 15, n. 2, p. 401-423, jul./dez. 2010. Doi: 10.5020/23172150.2010.v15n2p401.http://ojs.unifor.br/index.php/rpen/article/view/2133.

RUDOLF VON IHERING. In: WIKIPÉDIA, a enciclopédia livre. Flórida: Wikimedia Foundation, 2017. Disponível em: <https://pt.wikipedia.org/w/index.php?title= Rudolf_von_ Ihering\&oldid=48790844> . Acesso em: 13 maio 2017.

SALLES, José Carlos de Moraes. Usucapião de bens imóveis e móveis, 6. ed. São Paulo: RT, 2005.

SIQUEIRA, Marcelo Sampaio. Direito de construir - perfil constitucional e restrições: a função social em conflito com o direito de propriedade. Curitiba: Juruá, 2012. 
A perda da multipropriedade imobiliária por usucapião

STAFFEN, Marcio Ricardo. Multipropriedade imobiliária: entre o direito (real) posto e o pressuposto. Revista de Direito Imobiliário, v. 34, n. 71, p. 77-91, jul./dez. 2011.

TEPEDINO, Gustavo. Multipropriedade imobiliária. São Paulo: Saraiva, 1993.

ZAVASCKI, Teori Albino. A tutela da posse na Constituição e no Novo Código Civil. Revista Brasileira de Direito Constitucional, n. 5, p. 50-61, jan./jun. 2005.

Recebido em: 8 jun. 2017.

Aceito em: 17 nov. 2017 